\title{
Antonina Kozyrska
}

(Uniwersytet Mikołaja Kopernika w Toruniu)

\section{ROLA KOŚCIOLA KATOLICKIEGO W PROCESIE POJEDNANIA POLSKO-UKRAIŃSKIEGO PO 1989 R.}

Trudne stosunki polsko-ukraińskie w wieku XX nierzadko były naznaczone wzajemną niechęcią, uprzedzeniami, konfliktami i oskarżeniami o nacjonalizm. Wraz z przemianami ustrojowymi w Europie Środkowo-Wschodniej zaistniała potrzeba ułożenia dobrosąsiedzkich i partnerskich relacji między niepodległymi państwami - Polską i Ukrainą. W tym procesie ważną rolę odgrywał problem pojednania polsko-ukraińskiego. Transformacje społeczno-polityczne w Polsce i na Ukrainie po 1989 r. umożliwiły dyskusję publiczną na temat dziejów stosunków polsko - ukraińskich. Historycy obu krajów podjęli wszechstronne, oparte na źródłach badania, rozpoczęli wspólny dialog służący wyjaśnieniu ,białych plam" i odtworzeniu prawdy historycznej ${ }^{1}$. Pogłębiała się współpraca krajów w dziedzinie naukowo-kulturalnej, gospodarczej i politycznej. O prawdziwym porozumieniu można jednak mówić wówczas, gdy odbywa się ono międzynarodami, a nie tylko politykami². Masowa świadomość społeczna zmienia się jednak powoli, co dotyczy zwłaszcza pokolenia starszego i średniego. Ogrom emocji i dyskusje publiczne towarzyszące kolejnym rocznicom tragicznych wydarzeń z historii konfliktu polsko-ukraińskiego w minionym wieku wskazuje, że proces przejścia od deklaratywnego do realnego pojednania nadal trwa. Pomimo polepszenia się stosunków bilateralnych: gospodarczych, naukowo-kulturalnych, politycznych - masowa świadomość społeczna zmienia się powoli.

Działania na rzecz zbliżenia narodów były podejmowane w różnych środowiskach i na różnym szczeblu zarówno po stronie polskiej, jak i ukraińskiej. Uczyniono wiele gestów symbolicznych, jak wspólne apele i deklaracje o pojed-

${ }^{1}$ Od połowy lat dziewięćdziesiątych XX w. odbywają się na przemian w Polsce i na Ukrainie seminaria polsko-ukraińskie z cyklu „Polska - Ukraina: trudne pytania”. Ich pokłosiem jest seria wydawnicza o tej samej nazwie.

${ }^{2}$ A. Krzemiński, Widoczny znak pokoju, „Polityka”, 19-26 XII 2009, nr 51/52 (273), s. 126. 
naniu, udział w uroczystościach upamiętniających tragiczne wydarzenia z dziejów polsko-ukraińskich, otwarcie cmentarzy wojskowych we Lwowie, pomników upamiętniających ofiary mordów ludności polskiej ukraińskiej po obu stronach granicy. Przykładem takich działań było podpisanie 21 maja 1997 r. przez prezydentów Polski - Aleksandra Kwaśniewskiego i Ukrainy - Leonida Kuczmę wspólnego oświadczenia o porozumieniu i pojednaniu narodów polskiego i ukraińskiego. Przywódcy obu państw wyrazili w nim pragnienie, przezwyciężenia skomplikowanego dziedzictwa przeszłości³.

Deklarowali objęcie patronatu nad utrwaleniem idei zbliżenia i pojednania polsko - ukraińskiego. W tym samym roku, w którym przypadała 50. rocznica akcji „Wisła”, apel z tej okazji wystosowali polscy intelektualiści. Na początku 2003 r., w 60. rocznicę konfliktu zbrojnego na Wołyniu, ukraińscy intelektualiści w liście otwartym zachęcali do wzajemnego wybaczenia ${ }^{4}$.

Z tej także okazji w 2003 r. w Pawliwce (Porycku) na Wołyniu prezydenci A. Kwaśniewski i L. Kuczma odsłonili pomnik pojednania polsko-ukraińskiego „Pamięć - żałoba - jedność” oraz podpisali wspólną deklarację w tej sprawie 5 . Nie sposób nie zgodzić się z poglądem ukraińskiego historyka Wołodymyra Trofymowycza i który wiązał możliwość pojednania z porozumieniem całych społeczeństw, nie tylko elit ${ }^{6}$.

Na potrzebę przyśpieszenia procesu pojednania polsko-ukraińskiego zwrócił uwagę również Kościół katolicki. Uczynił to ze względu na swoją pokojową misje w świecie. Parafrazując wypowiedź Tomasa Venclovy wszak zadaniem Kościoła jest budzić sumienia ${ }^{7}$. Kościół włączył się w proces porozumienia między sąsiednimi narodami również z wewnętrznej potrzeby polepszenia wzajemnych relacji wiernych obrządku greckiego i łacińskiego po obu stronach granicy. Dystans w relacjach katolików obu rytów na Ukrainie i w Polsce jest konsekwencją trudnej spuścizny historycznej narodów polskiego i ukraińskiego. Wierni Kościoła rzymskokatolickiego tradycyjnie utożsamiani byli, bowiem z narodowością polską i odpowiednio grekokatolicy - z ukraińską. Postrzeganie takie jest nadal popularne, chociaż władze i duchowieństwo Kościoła rzymskokatolickiego usi-

${ }^{3}$ Wspólne oświadczenie prezydentów Polski i Ukrainy o porozumieniu i pojednaniu obu narodów, „Biuletyn Południowo-Wschodniego Instytutu Naukowego” (Przemyśl) 1997, nr 3, s. 151.

${ }^{4}$ List otwarty $w$ zwiąku z 60. rocznica ukraińsko-polskiego konfliktu zbrojnego na Wotyniu, „Biuletyn Ukrainoznawczy” 2003, nr 8, s. 11-12. Tekst oryginalny zob.: „Ï. Незалежний Культурологічний Часопис" (Львів), 2003, nr 28, s. 2-3.

${ }^{5}$ B. S u r m a c z, Ukraina w stosunkach międzynarodowych, red. M. Pietraś, T. Kapuśniak, Lublin 2007, s. 212.

${ }^{6}$ В. Т р о фи м о в и ч, Примирення не можна приурочити до певної дати, [w:] Війни і Мир, або „, Українці - поляки: брати/вороги, сусіди...”, red. Л. Івшина, Київ 2004, s. 348.

${ }^{7}$ Venclova użył tych słów w odniesieniu do zadania pisarza. Zob. odpowiedź na list otwarty A. Źuvintasa (1978) w ramach dyskusji na temat stosunków litewsko-żydowskich. T. Ve n c lo v a, Eseje. Publicystyka, Sejny 2000, s. 159. 
łują to zmienić ${ }^{8}$. Grekokatolicy ukraińscy wywarli niemały wpływ na odbudowę życia narodowego, umacnianie tożsamości ukraińskiej. Z drugiej strony, zbytnie akcentowanie spraw narodowych w życiu Kościołów również dziś prowadzi do wielu nieporozumień w ich wzajemnych relacjach?

Zdaniem Olega Turija, źródła niektórych napięć między katolikami obu rytów leżą także w historycznej zmianie ról obydwu Kościołów. Obecnie katolicy obrządku rzymskiego na Ukrainie stanowią mniejszość nie tylko wyznaniową, ale także mniejszość w gronie wyznawców katolicyzmu. W tej sytuacji przed unitami stoi wyzwanie - nie wykorzystywać własnej przewagi w celu rewanżu historycznego, lecz do usunięcia występujących nieporozumieńoraz do nawiązania współpracy.

Władze i duchowieństwo Kościoła rzymskokatolickiego oraz greckokatolickiego w Polsce i na Ukrainie podejmowały wiele inicjatyw na rzecz zbliżenia sąsiednich narodów. Zanim jednak doszło do konkretnych czynów o potrzebie zwiększenia roli Kościoła katolickiego w procesie pojednania polsko-ukraińskiego wielokrotnie pisała paryska „Kultura”. Mówili o tym na jej łamach zarówno prekursorzy pojednania sąsiednich narodów - Jerzy Giedroyć i Bohdan Osadczuk. Dopiero w drugiej połowie lat 80 . minionego stulecia, w przededniu zbliżającego się wielkiego jubileuszu Milenium Chrztu Rusi uczyniono pierwsze kroki w tym kierunku. W październiku 1987 r. w Rzymie odbyło się oficjalne spotkanie hierarchów polskich z ukraińskimi. Urzędujący w Rzymie zwierzchnik Ukraińskiego Kościoła Greckokatolickiego kardynał Myrosław Lubacziwski podkreślając wagę i radość z tego spotkania oraz wzorując się na liście biskupów polskich zwrócił się ze słowami: „My - hierarchia ukraińskiego Kościoła katolickiego - wyciągamy braterską dłoń do Braci Polaków na znak pojednania, przebaczenia i miłości”10.

W odpowiedzi prymas Polski Józef Glemp przywołał polsko-ukraińską wspólnotę przeszłości kulturowej i religijnej przestrzegając przed wzajemnym oskarżaniem $^{11}$. Jak się później okazało, deklaracja z 1987 r. nie została wystarczająco poparta czynami, co powodowało wzrost napięcia we wzajemnych stosunkach obydwu Kościołów.

${ }^{8}$ Szerzej na ten temat zob.: J. Ri e ge r, Identyfikacja narodowa i religijna Polaków na Ukrainie, [w:] Trudna tożsamość. Problemy narodowościowe i religijne $w$ Europie Środkowo-Wschodniej w XIX i XX wieku, red. J. Lewandowski, Lublin 1996, s. 110-130; Н. Ко ч а н, EmноконфесійністереотиписучасноїУГКЦ. РКЦ як „,польська иерква” в Украӥні, „Наукові Записки” (НАНУ, Інститут Політичних і Етнонаціональних Досліджень) 2006, t. 29, s. 300-328.

${ }^{9}$ O. T u rij, Życie religijne oraz stosunki międzywyznaniowe $w$ niepodległej Ukrainie, [w:] Tożsamość wyznaniowa i dialog jako czynnik opiniotwórczy w ramach kultury narodowej. Doświadczenia Białorusi, Ukrainy i Polski, red. K. Klauza, Lublin 2008, s. 63.

${ }^{10}$ M. M e 1 n y k, Rola prezydenta RP Aleksandra Kwaśniewskiego oraz hierarchów Kościoła w pojednaniu i dialogu polsko-ukraińskim na przestrzeni ostatnich lat, „Biuletyn Ukrainoznawczy” (Przemyśl) 2003, nr 9, s. 90-91.

${ }^{11}$ G. Pr z e b in d a, Większa Europa. Papież wobec Rosji i Ukrainy, Kraków 2001, s. 287. 
W roku następnym Jasna Góra stała się centrum polskich obchodów Tysiąclecia Chrztu Rusi. W tym świętym miejscu zgromadzili się licznie na wspólnej modlitwie Polacy obrządku rzymskokatolickiego oraz po raz pierwszy od $1947 \mathrm{r}$. ukraińscy grekokatolicy z Polski i z całego świata. Także w latach następnych takie łączenie się Polaków i Ukraińców na wspólnej modlitwie stało się ważnym elementem dialogu polsko-ukraińskiego ${ }^{12}$.

Kilka takich spotkań modlitewnych w intencji polsko-ukraińskiego pojednania odbyło się w Lublinie. Na przykład 20 lutego 2002 r. w kościele św. Andrzeja Boboli odprawiono mszę świętą z udziałem 9 biskupów i ponad 60 duchownych katolickich obrządku łacińskiego i greckiego. Nabożeństwu przewodniczył zwierzchnik Kościoła greckokatolickiego na Ukrainie kardynał Lubomyr Huzar. Symboliczny wydźwięk miał wystrój świątyni, przygotowany na tę okazję. W kościele zbudowano ikonostas przedstawiający świętych polskich i ukraińskich. W roku 2004 w dniu 18 lutego uroczyste nabożeństwo zostało odprawione w archikatedrze lubelskiej. Wzięli w nim udział kard. L. Huzar, biskupi obu Kościołów z Ukrainy i Polski oraz liczni wierni. Dwa lata później 22 września 2006 r. podobna inicjatywa miała miejsce na Majdanku. Oprócz hierarchów w modlitwie uczestniczyła polska i ukraińska młodzież. Podobne spotkania odbywały także w wielu innych miejscach, jak w Podkowie Leśnej jeszcze 3 czerwca 1984 r. czy w Białym Borze w Koszalińskiem 24 września 2000 r. ${ }^{13}$ Od 2002 r. w uroczystość Wszystkich Świętych nabożeństwa polsko-ukraińskie odbywają się na Cmentarzu Łyczakowskim we Lwowie. W czerwcu 2003 r. w Drohiczynie w Polsce odprawiono wspólną mszę świętą z okazji 750-rocznicy koronacji księcia halickiego Daniela Romanowicza ${ }^{14}$.

Na potrzebę wzajemnego przebaczenia i zbliżenia narodu polskiego i ukraińskiego wskazał papież Jan Paweł II - orędownik pokoju i pojednania między narodami. Już na początku swojego pontyfikatu w encyklice o miłosierdziu Bożym Dives in misericordia z $1980 \mathrm{r}$. nauczał o istocie aktu wybaczenia ${ }^{15}$.

O potrzebie zbliżenia narodów polskiego i ukraińskiego mówił 26 czerwca $2001 \mathrm{r}$. w trakcie homiliii ${ }^{16}$.

Zdaniem Grzegorza Przebindy, ,Jan Paweł II potrafił w ciągu paru dni wyciszyć wiele zastarzałych sporów" ${ }^{17}$. Za najbardziej znamienne pod tym względem uznał spotkanie papieża z młodzieżą we Lwowie w dniu 26 czerwca, kiedy to

${ }^{12} \mathrm{~S} . \mathrm{B}$ a tr u c h, Inicjatywy dialogu przez budowanie tożsamości wyznaniowej na pograniczu polsko-ukraińskim, [w:] Tożsamość wyznaniowa i dialog jako czynnik opiniotwórczy w ramach kultury narodowej, red. K. Klauza, Lublin 2008, s. 83.

${ }^{13}$ G. Pr z e b in d a, Większa Europa..., s. 282, 321.

${ }^{14}$ В. Перевезій, Проблеми украйнсько-польського порозуміння на початку ХХІ століття та роль релігійних організацій в їх розв 'язанні, „Наукові Записки” (НАНУ ІПЕНД) 2006, t. 29, s. 334.

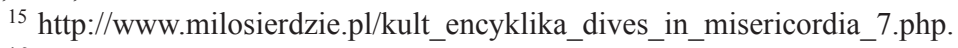

${ }^{16}$ Homilia Jana Pawła II wygłoszona podczas Mszy św. beatyfikacyjnej we Lwowie, „Biuletyn Prasowy KAI", 29 VI 2001, nr 52, s. 74.

${ }^{17}$ G. Prze bind a, Większa Europa..., s. 225. 
„zgodnie szumiały na wietrze sztandary niepodległej Ukrainy i flagi zjednoczonej Europy, a Papież dialogował z młodymi w języku ukraińskim i po polsku" ${ }^{18}$. Rzeczywiście, w czasie wizyty papieskiej na Ukrainie zapanował tam wyjątkowy klimat zgody. Podróżując po ziemi ukraińskiej Ojciec Święty podkreślał miejscowe tradycje wielokulturowości i tolerancji religijnej. Nazywał ten kraj ojczyzną pokojowego współistnienia różnych narodowości i religii, miejscem skrzyżowania Wschodu z Zachodem, gdzie „spotkały się dwie wielkie tradycje chrześcijańskie, bizantyjska i łacińska, i obie znalazły przychylne przyjęcie"19. Przychylne wypowiedzi Jana Pawła II pod adresem narodu ukraińskiego, który określał szlachetnym, swobodne posługiwanie się w przemówieniach językiem ukraińskim wpłynęło na przekonanie społeczeństwa ukraińskiego o tym, że Papież Polak jest wielkim przyjacielem Ukraińców. Co więcej, jeszcze w czasie przygotowań tej wizyty i w jej trakcie na Ukrainie była szeroko rozpowszechniona opinia, że papież po kądzieli ma ukraińskie korzenie ${ }^{20}$. Wyraz wiary w bliską więź Jana Pawła II z Ukrainą dał minister spraw zagranicznych Ukrainy Borys Tarasiuk na konferencji prasowej 22 grudnia 2005 r. Wskazując na wielką stratę dla ludzkości, jaką stała się śmierć Jana Pawła II, nazwał go: „Wielkim Polakiem i Ukraińcem, kaznodzieją pokoju, jedności i miłości, których Ukraińcy bardzo potrzebują"21.

Działania na rzecz pojednania polsko-ukraińskiego podjęła działająca od $1996 \mathrm{r}$. Ogólnoukraińska Rada Kościołów i Organizacji Religijnych, która zrzesza największe Kościoły i związki religijne kraju. W dniu 12 maja 2003 r. wystosowała odezwę z okazji 60. rocznicy tragicznych wydarzeń na Wołyniu i w Galicji Wschodniej22. Jednymi z inicjatorów tej odezwy były Cerkwie prawosławne na Ukrainie - Ukraińska Autokefaliczna Cerkiew Prawosławna i Ukraińska Prawosławna Cerkiew Patriarchatu Kijowskiego, które dominują na Wołyniu. Miesiąc później Rada zwróciła się do papieża Jana Pawła II z prośbą o skierowanie słowa pokoju do wiernych różnych wyznań chrześcijańskich na Ukrainie - Polaków i Ukraińców ${ }^{23}$.

18 Ibidem.

19 Przemówienie podczas spotkania z przedstawicielami świata polityki, kultury i sztuki w pałacu Mariańskim, 23 VI 2001. Прочанинмирутанадіï, Київ 2004. Sam Lwów przed II wojną światową był miejscem w Polsce wyjątkowym, symbolem wielokulturowości. W mieście przez długie wieki mieszkali obok siebie przedstawiciele wielu narodów: Polacy, Ukraińcy, Żydzi, Ormianie, Niemcy, Tatarzy i in. Tu mieli swoją siedzibę metropolici Kościoła katolickiego trzech obrządków - łacińskiego, greckiego oraz ormiańskiego.

${ }^{20}$ К. Г уд з и к, „Папа як і ви, є Слов'янином”, [w:] Війни і мир, або „, Украӥнці - поляки: брати/ вороги, сусіди...”, ред. Л. Івшиної, Київ 2004, s. 501.

21 Виступ Міністра закордонних справ України Бориса Тарасюка на прес-конферениії 3 нагоди Дня Української дипломатії і зовнішньополітичних підсумків 2005 p., http://www.mfa. gov.ua/mfa/ua/-publication/content/4950.htm (dostęp 27 IV 2008).

22 У Державному комітеті у справах релігій. Офіиійний вісник, „Людина і Світ” 2003, nr 5, s. 29.

23 У Державному комітеті у справах релісій. Офіиіийний вісник, „Людина і Світ” 2003, nr 6, s. 37 . 
Papież odpowiedział na tę prośbę listem 7 lipca 2003 r., adresowanym w pierwszej kolejności do zwierzchników Kościołów katolickich w Polsce i na Ukrainie - kardynałów Józefa Glempa, Mariana Jaworskiego i Lubomyra Huzara oraz „bratnich narodów Ukrainy i Polski”24. Mówiąc o konieczności dokonania rachunku sumienia i wzajemnego szczerego wybaczenia win Jan Paweł II proponował kierować się postawą Kościoła katolickiego w czasie Wielkiego Jubileuszu w 2000 r. Wówczas papież w imieniu całego Kościoła przeprosił ludzkość za popełnione w przeszłości grzechy swoich wiernych i przebaczył wszystkim, którzy wyrządzili mu krzywdy. Ojciec święty zachęcał do spojrzenia na bolesne wydarzenia przeszłości w nowej perspektywie, aby wychowywać młode pokolenie i budować lepszą przyszłość bez obciążeń historycznych, nawarstwionej nieufności, przemocy i uprzedzeń. Na koniec Jan Paweł II wyraził radość z powodu zaplanowanych na 11 lipca polsko - ukraińskich obchodów tej rocznicy, które w jego przekonaniu będą sprzyjać zbliżeniu narodów.

List papieski został wkrótce odczytany podczas uroczystości odsłonięcia pomnika pojednania polsko - ukraińskiego w Pawliwce (Porycku) na Wołyniu 11 lipca. Miejsce to stanowi jeden ze smutnych symboli ludzkiej nienawiści. Dokładnie 60 lat wcześniej w miejscowym kościele żołnierze UPA wymordowali większość polskich mieszkańców wsi, którzy zgromadzili się na niedzielnej sumie ${ }^{25}$.

Pomnik został poświęcony przez kard. M. Jaworskiego. W intencji ofiar została odprawiona msza św., której przewodniczył wspomniany kardynał w koncelebrze z biskupem pomocniczym Leonem Małym, ordynariuszem łuckim Markijanem Trofimiakiem i biskupem polowym Wojska Polskiego Sławojem Głódziem. W uroczystościach wzięli udział również przedstawiciele Ukraińskiego Kościoła Greckokatolickiego, z kard. L. Huzarem na czele, oraz innych wyznań. W homilii kard. Jaworski tłumaczył, że przykazanie miłości bliźniego dotyczy nie tylko swoich, ale także innych narodów i wyznań, nawet nieprzyjaciół. Wydarzenie w Pawliwce nazwał milowym krokiem w stosunkach polsko-ukraińskich. Po nabożeństwie katolickim odbyły się modły ekumeniczne ${ }^{26}$. W ogłoszonym w tym dniu wspólnym oświadczeniu prezydentów Polski i Ukrainy przywódcy państw odwoływali się m.in. do apelu Jana Pawła II o pojednaniu, wypowiedzianego w czasie jego pielgrzymki we Lwowie.

Wspólne spotkania, deklaracje i apele o pojednaniu sprzyjają tworzeniu dobrego klimatu w dialogu polsko-ukraińskim. Po 1989 r. pojawiały się jednak problemy, które były sprawdzianem deklarowanych dobrych intencji i wskazy-

${ }^{24} \mathrm{~J}$ a n P a w e 1 II, List z okazji 60. rocznicy tragicznych wydarzeń na Wolyniu, „Biuletyn Ukrainoznawczy" (Przemyśl) 2003, nr 9, s. 9.

${ }^{25}$ Kazanie wygłoszone przez bp. polowego WP Sławoja Leszka Głódzia podczas Mszy świętej odprawionej w Pawliwce w intencji Polaków pomordowanych na Wołyniu, „Biuletyn Ukrainoznawczy" (Przemyśl) 2003, nr 9, s. 119.

${ }^{26} \mathrm{~S}$. S t ę p i e ń, Wolyń 1943 - historyczna retrospekcja oraz uroczystości po 60 latach, „Biuletyn Ukrainoznawczy" (Przemyśl) 2003, nr 9, s. 106-108. 
wały na rzeczywisty stan zaawansowania procesu zbliżenie narodów polskiego i ukraińskiego. Jednym $z$ takich trudnych wyzwań okazała się sprawa otwarcia Cmentarza Orląt na cmentarzu Łyczakowskim we Lwowie. W zakresie ochrony miejsc pamięci i spoczynku osób poległych lub pomordowanych w czasie wojen i represji politycznych Polska i Ukraina mają podpisane odpowiednie umowy bilateralne ${ }^{27}$. Ich praktyczna realizacja napotkała jednak szereg komplikacji, powodując impas w dwustronnych stosunkach polsko - ukraińskich. Kontrowersje wokół Cmentarza Orląt trwały ponad dekadę i miały charakter wojny o symbole. Działania, podejmowane na szczeblu najwyższych władz państwowych obu państw, długo nie odnosiły skutku, gdyż ostateczne decyzje należały do władz samorządowych Lwowa. Kością niezgody okazał się nie tyle sam cmentarz, co napis na mogile polskiego nieznanego żołnierza. Rada Miejska Lwowa uniemożliwiała otwarcie Cmentarza Orląt obawiając się powstania, zamiast cmentarza wojskowego, polskiego panteonu chwały na ziemiach niepodległego państwa ukraińskiego. Na tle architektury Cmentarza Orląt znajdujący się obok pomnik ukraińskich Strzelców Siczowych, zbudowany w kilka dni przed przyjazdem do Lwowa prezydenta L. Kuczmy w 1999 r., prezentował się dość „,skromnie"28. Wówczas prezydent Ukrainy wspólnie z prezydentem Polski A. Kwaśniewskim złożyli kwiaty na grobach żołnierzy polskich i ukraińskich na cmentarzu Łyczakowskim. Radni Lwowa jednak skutecznie blokowali kilkakrotnie planowane uroczystości otwarcia polskiego cmentarza wojskowego. Nie doszło do skutku otwarcie cmentarza, zaplanowane na maj 2002 r. Aleksander Kwaśniewski odwołał swoją wizytę we Lwowie ${ }^{29}$.

Powyższy bieg wydarzeń uruchomił lawinę krytyki ze strony polskiej i ukraińskiej. Podważając decyzje radnych, środowisko ukraińskiego niezależnego pisma kulturologicznego „Ji” w oświadczeniu z 22 maja 2002 r. zarzuciło prezydentowi Ukrainy brak zainteresowania sprawą. Co więcej, wyrażono obawy, że może ona być dla niego okazją do wycofania się z europejskiego kierunku polityki zagranicznej państwa. Inną inicjatywą lwowskich intelektualistów dotyczącą zakończenia omawianego problemu był list otwarty do prezydentów Polski i Ukrainy z 17 czerwca 2002 r. Wskazywano w nim na ważną rolę, jaką powinien odegrać Kościół ${ }^{30}$.

${ }^{27} \mathrm{~J} . \mathrm{R}$ e z m e r, Ochrona miejsc pamięci i spoczynku ofiar wojny i represji politycznych między Rzeczypospolita Polska a Ukraina w świetle polsko-ukraińskich porozumień dwustronnych, [w:] Nad Wista i Dnieprem. Polska i Ukraina w przestrzeni europejskiej - przeszłość a teraźniejszość, Toruń-Kijów 2002.

${ }^{28}$ М. Р я бч ук, Дилеми украӥнського Фауста: громадянське суспільство $i$ „розбудова держсави”, Київ 2000, s. 216.

${ }^{29}$ Я. М а щ а к, Польсько-украӥнські відносини в 1999-2002 роках, [w:] Nad Wista i Dnieprem..., s. 337-338.

${ }^{30} \mathrm{http}: / / w w w . j i-m a g a z i n e .1 v i v . u a /$ seminary/2002/krstil-111/krstil-1lyst.htm (dostęp $15 \mathrm{X}$ 2010). 
Podobne działania podjęła strona polska. W lipcu 2002 r. przedstawiciele środowisk twórczych, naukowych, społecznych i politycznych w Polsce wystosowali List otwarty do Polaków i Ukraińców dobrej woli w sprawie Cmentarza Orląt.

Tymczasem władze kościelne na Ukrainie nie pozostawały bierne. Zwierzchnicy Kościoła rzymskokatolickiego oraz greckokatolickiego na Ukrainie kardynałowie Lumomyr Huzar i Marian Jaworski wiosną 2002 r. zwracali się w tej sprawie do władz samorządowych i centralnych oraz apelowali do swoich wiernych. Dnia 18 czerwca tegoż roku kard. Huzar wystosował apel do swoich wiernych oraz wszystkich ludzi dobrej woli w sprawie uszanowania wojskowych cmentarzy na Łyczakowie. W nim nawiązał do rocznicy pielgrzymki Jana Pawła II na Ukrainę i klimatu jedności, który wówczas zapanował w kraju. Zdaniem kardynała to duchowe uniesienie określiło wysoki poziom duchowy, z perspektyw, którego należało podchodzić do problemów życia narodowego i wyzwań codzienności ${ }^{31}$.

Hierarcha wezwał chrześcijan, aby do momentu rozwiązania problemu przez czynniki państwowe jednoczyć się na wspólnej modlitwie nad grobami poległych i przygotować własne serca, wypełniając je pokojem i miłością. Wkrótce 4 lipca 2002 r. obaj kardynałowie ogłosili apel do wszystkich ludzi dobrej woli wzywający do zgody i do uszanowania wszystkich, którzy przelewali krew za swoją ojczyznę. W uroczystość Wszystkich Świętych 1 listopada tegoż roku obaj hierarchowie wspólnie złożyli wieńce na grobach żołnierzy polskich i ukraińskich na Cmentarzu Łyczakowskim. Kardynał Huzar tłumaczył ten gest, jako swój obowiązek i próbę wyjścia ponad bycie „zakładnikami przeszłości” ${ }^{32}$. W ten sposób wreszcie cmentarze, które przez długie lata były symbolem sporu polsko - ukraińskiego, stały się miejscem spotkania ${ }^{33}$.

W tym samym dniu we Lwowie odbył się polsko-ukraiński okrągły stół zatytułowany Jak nam poradzić ze wspólna historia? Zgromadził on około setki działaczy kościelnych, w tym wspomnianych kardynałów, kulturalnych, społecznych, a także naukowców, polityków i dziennikarzy z Polski i Ukrainy. Główne referaty wygłosili Jacek Kuroń i prof. Myrosław Marynowycz. W ocenie Marka Melnyka, przed wspomnianą datą zaangażowanie Kościołów w zakończenie omawianego konfliktu mimo wszystko było zbyt słabe. Szczególnie brak ich mediacyjnej roli oraz zdecydowanych wypowiedzi hierarchów wpłynęły na niekorzystne przeciąganie się tej sprawy ${ }^{34}$.

${ }^{31}$ Блаженніший Любомир кардинал Гузар о прилюднивзвернення зприводувщануваннявійсь ковихпохованьна Личаківському иявнтаріу Львові, 20 VI 2002, http://www.ji-magazine. lviv.ua/inform/-orlata/m-pr2006.htm (dostęp 3 X 2010).

32 Z kard. Lubomirem Huzarem, zwierzchnikiem Ukraińskiego Kościoła Greckokatolickiego, rozmawia Jan Strzałka, „Tygodnik Powszechny” 2002, nr 46.

${ }^{33} \mathrm{~B}$. B e r d y c z o w s k a, Wolyń - wspólna refleksja nad przeszłościa, czy samotne rozpamiętywanie o krzywdzie?, „Biuletyn Ukrainoznawczy” (Przemyśl) 2003, nr 9, s. 98.

${ }^{34}$ M. M e ln y k, Rola prezydenta ..., s. 89. 
5 maja następnego roku, w którym obchodzono 60. rocznicę tragicznych wydarzeń na Wołyniu i Galicji Wschodniej, biskupi metropolii halicko-kijowskiej Ukraińskiego Kościoła Greckokatolickiego wydali list pasterski Do narodów ukraińskiego i polskiego - sąsiadów, braci w Chrystusie. Celem opublikowania listu było nie tyle polityczne, ile duchowno-religijne pojednanie - jak to ujęli hierarchowie ${ }^{35}$.

$\mathrm{Na}$ oficjalne otwarcie Cmentarza Orląt przyszło czekać jeszcze dwa lata. Stało się to możliwe dopiero po zmianie ekipy rządzącej na Ukrainie w następstwie pomarańczowej rewolucji. Uroczystości odbyły się 24 czerwca 2005 r. z udziałem prezydentów Polski A. Kwaśniewskiego i już nowego prezydenta Ukrainy Wiktora Juszczenki, którego aktywna interwencja wreszcie przyniosła długo oczekiwany sukces. W uroczystości otwarcia wzięli udział lwowscy kardynałowie L. Huzar i M. Jaworski. Elementem uroczystości było również odsłonięcie Memoriału Wyzwoleńczych Zmagań Narodu Ukraińskiego ku czci żołnierzy Ukraińskiej Armii Halickiej, poległych w wojnie polsko-ukraińskiej w latach 1918-1919. Powyższe fakty poprzedziło inne wydarzenie w Polsce, które miało wielką wymowę symboliczną. Dnia 19 czerwca w czasie mszy św. na placu Piłsudskiego biskupi Kościoła Rzymskokatolickiego w Polsce, na czele z prymasem Polski i Kościoła Greckokatolickiego z Ukrainy, dokonali symbolicznego aktu wzajemnego przebaczenia i pojednania. $Z$ tej okazji ogłosili oni wspólny apel zatytułowany Pojednanie jest możliwe. W uroczystej liturgii, która wieńczyła III Krajowy Kongres Eucharystyczny, uczestniczyli również hierarchowie z innych krajów postradzieckich ${ }^{36}$. Wspomniany apel o pojednaniu został odczytany 26 czerwca na Ukrainie w czasie odbywającego się we Lwowie Ogólnokrajowego Kongresu Eucharystycznego Ukraińskiego Kościoła Greckokatolickiego. Następnie została odmówiona modlitwa o pojednaniu między ukraińskim i polskim narodami. Wygłosili ją symbolicznie po sześć osób z każdej ze stron, reprezentujący różne stany: biskup, kapłan, małżeństwo, dziewczyna i chłopak ${ }^{37}$.

Niestety, nawet po oficjalnym otwarciu cmentarza dyskusje wokół znajdujących się na nim symboli i napisów nie ustały. Pozostała natomiast piękna tradycja wspólnej modlitwy Polaków i Ukraińców nad grobami poległych z obu stron, zapoczątkowana przez hierarchów 1 listopada 2002 r. Niecały rok po otwarciu Cmentarza Orląt w tym miejscu w dniu Wszystkich Świętych tradycyjnie została odprawiona msza św., celebrowana przez kard. M. Jaworskiego w asyście biskupów pomocniczych archidiecezji lwowskiej M. Buczka i L. Małego oraz duchowieństwa. Kościół greckokatolicki reprezentował ojciec mitrat M. Dymyd. Po nabożeństwie na polskim cmentarzu wojskowym jego uczestnicy przeszli na

${ }^{35}$ Z przestania hierarchy Kijowsko-Hałyckiej metropolii Ukraińskiego Kościoła greckokatolickiego do narodów ukraińskiego i polskiego - sąsiadów, braci w Chrystusie, „Ukraïna” 2005, nr 1, s. 89.

${ }^{36}$ A. Kr z y żan i a k - G u m o w s k a, W. S z a c k i, Pojednanie Kościołów Polski i Ukrainy, „Gazeta Wyborcza”, 19 VI 2005.

${ }^{37}$ П е р е в е з і й, Проблеми украӥнсько-польського порозуміння, s. 337. 
sąsiedni cmentarz i uczcili pamięć żołnierzy ukraińskich ${ }^{38}$. Obecny wówczas na modlitwie Ukrainiec, mieszkaniec Lwowa, ubolewał jednak, że w odróżnieniu od społeczności polskiej w tej pięknej tradycji wspólnej modlitwy uczestniczyło bardzo mało Ukraińców - zarówno duchownych, jak i wiernych ${ }^{39}$. Z czasem w organizację następnych spotkań modlitewnych na Łyczakowie włączył się m.in. lwowski Ukraiński Katolicki Uniwersytet, genewskie Towarzystwo im. W. Sołowiowa, niezależne kulturoznawcze pismo „Ji”40.

Kompromis, zawarty w sprawie Cmentarza Orląt, umożliwił także realizację jednego z postulatów strony ukraińskiej - odsłonięcia memoriału pomordowanych w 1945 r. Ukraińców na cmentarzu greckokatolickim we wsi Pawłokoma na Podkarpaciu w Polsce ${ }^{41}$. Pomnik został odsłonięty 13 maja 2006 r. w obecności prezydentów Polski Lecha Kaczyńskiego i Ukrainy Wiktora Juszczenki. Poświęcenia pomnika dokonali kardynał Lubomyr Huzar oraz ordynariusz rzymskokatolickiej diecezji przemyskiej Józef Michalik. Na cmentarzu greckokatolickim zostało odprawione nabożeństwo żałobne w intencji ofiar. Następnie prezydenci uczcili również pamięć Polaków z Pawłokomy, którzy zginęli z rąk UPA. Nie znalazła natomiast dotychczas finału sprawa powrotu na cmentarz Orląt Lwowskich szczątków arcybiskupa katolików ormiańskich Józefa Teodorowicza (1864-1938). Był on zasłużonym dla Polski politykiem, honorowym obywatelem Lwowa. W czasach komunistycznych w obawie przed profanacją jego szczątki zostały potajemnie przeniesione do cudzego grobowca i umieszczone pod obcym nazwiskiem. W ramach prac renowacyjnych na Cmentarzu Orląt odnowiono grobowiec arcybiskupa, jednak pozostaje on pusty. Środowisko Ormian w Polsce od 1991 r. stara się o godny pochówek dla swojego arcybiskupa. Starania te aktywnie wsparły władze kościelne Polski i Ukrainy, w tym szczególnie rzymskokatolicka archidiecezja lwowska z kard. M. Jaworskim na czele, a także władze obu krajów i polscy posłowie. Sprawa jednak pozostaje otwarta z powodu nieprzejednanego stanowiska władz miejskich Lwowa ${ }^{42}$.

Pomimo powstających trudności proces porozumienia polsko-ukraińskiego stopniowo rozwijał się. Często było to zasługą konkretnych ludzi, instytucji i or-

${ }^{38}$ К. Ч а в а г а, Дорогою до Бога не є багнет, не шабля, а примирення $і$ взаємне вибачення, „Львівська Газета”, 3 XI 2006, nr 30.

${ }^{39}$ Б. П а н ке в и ч, Усе щее холодно..., „Львівська Газета”, 6 XI 2006, nr 31.

${ }^{40}$ П е р е в е з і й, Проблеми..., s. 336.

${ }^{41}$ Zob. rozmowę z prof. P. Poticznym, który urodził się w Pawłokomie (Meandry ukraińskiej historii, [w:] Wiele twarzy Ukrainy, rozmawiali i przyp. opatrzyli I. Chruślińska i P. Tyma, Lublin 2005, s. 209-216.

${ }^{42}$ A. S z u m ań s k i, Ormianie polscy, http://www.rodaknet.com/rp_szumanski_39.htm (dostęp 12 IX 2010). Zob. także głos ks. Isakowicza-Zaleskiego w dyskusji panelowej „Ukraina - nowe wyzwanie dla Europy”, 9 XI 2005 r., na konferencji w Krakowie. Między religia a kultura w Europie. Chrześcijaństwo - islam - laicyzm. Rola Kościoła katolickiego w procesie integracji europejskiej, red. M. Góra, R. Budnik, Gliwice 2005, s. 65. 
ganizacji. W taki sposób zrodził się pomysł specjalnego wyróżnienia tych szczególnie zasłużonych, którzy swoją postawa i działalnością budują mosty porozumienia i stanowią wzór do naśladowania. Od 2001 r. jest przyznawana Nagroda Polsko - Ukraińskiego Pojednania, którą co roku zostaje uhonorowany jeden Polak i jeden Ukrainiec. Trzydziestoosobową Kapitułę, która przyznaje nagrodę, tworzą polscy i ukraińscy intelektualiści, politycy, dziennikarze oraz hierarchowie Kościołów. Obok takich postaci jak Zbigniew Brzeziński, Tadeusz Mazowiecki w skład Kapituły weszli również biskupi - zwierzchnik Kościoła greckokatolickiego na Ukrainie kardynał L. Huzar i metropolita przemysko-warszawski Kościoła greckokatolickiego w Polsce arcybiskup Jan Martyniak ${ }^{43}$. Pierwszą Nagrodę Polsko - Ukraińskiego Pojednania wręczył laureatom papież Jan Paweł II w czasie swojej pielgrzymki do Lwowa. Zostali nią wyróżnieni profesorzy Jerzy Kłoczowski z Lublina i Iwan Wakarczuk ze Lwowa. W jednej z kolejnych edycji nagroda została przyznana dyrektorowi Instytutu Ukrainoznawstwa Ukraińskiej Akademii Nauk we Lwowie prof. Jarosławowi Isajewiczowi, byłemu ministrowi spraw zagranicznych prof. Adamowi Rotfeldowi oraz redakcjom polskiego „Tygodnika Powszechnego” i ukraińskiej „Krytyki”. Nagroda została wręczona laureatom w czasie uroczystości poświęcenia Kaplicy Wszystkich Świętych Narodu Ukraińskiego w Sanktuarium Miłosierdzia Bożego w Łagiewnikach 24 czerwca 2007 r. Kaplica została dedykowana pojednaniu polsko-ukraińskiemu, do którego nawoływał Jan Paweł II. W obrządku konsekracji, a następnie we mszy św., odprawionej w rycie greckokatolickim, wziął udział episkopat Kościołów katolickiego i greckokatolickiego w Polsce, na Ukrainie i Białorusi ${ }^{44}$. Pozostałymi laureatami Nagrody Pojednania są: Jacek Kuroń oraz pisarz, krytyk literacki Mykoła Riabczuk (2002), dziennikarz Paweł Smoleński i historyk sztuki Borys Woznycki (2003), reżyser Jerzy Hofman i aktor Bohdan Stupka (2008), profesorowie historii Grzegorz Motyka i Ihor Iljuszyn (2009), dziennikarz Marcin Wojciechowski i Jurij Makarow, reżyser dokumentalista i prezenter telewizyjny (2010). W Polsce zostały odznaczone również zasługi kardynała Lubomyra Huzara na rzecz zbliżenia narodów polskiego i ukraińskiego. W październiku 2002 r. w Sali Unii Lubelskiej na Zamku w Lublinie odebrał on Medal Unii Lubelskiej, przyznawany przez władze tego miasta za zasługi w zbliżeniu Europy Wschodu i Zachodu ${ }^{45}$.

Dopiero na początku nowego stulecia zaczęto stawiać pierwsze kroki na drodze lepszego poznania się Kościoła rzymskokatolickiego w Polsce i Ukraińskiego Kościoła Greckokatolickiego. W tym celu 2003 r. podjęto wspólną decyzję o utworzeniu polskiego i ukraińskiego zespołów do spraw wzajemnych kontak-

\footnotetext{
${ }^{43}$ I. M e 1 n y k, Rok bez Nagrody pojednania, „Ukraïna” 2005, nr 1, s. 94-95.

${ }^{44}$ M. D o brzyniak, Lagiewniki: kaplica dedykowana pojednaniu polsko-ukraińskiemu, http://storico.-radiovaticana.org/pol/storico/2007-06/141191 (dostęp 14 X 2010).

${ }^{45}$ We wtorek uhonorowano w Lublinie kardynała Lubomyra Huzara ze Lwowa, zwierzchnika Ukraińskiego Kościoła Greckokatolickiego, „Gazeta Wyborcza”, 15 X 2002.
} 
tów Konferencji Episkopatu Polski z Kościołem Greckokatolickim na Ukrainie. Przewodniczącym polskiego zespołu został abp Sławoj Leszek Głódź. Konferencja Episkopatu Polski ma podobne zespoły ds. kontaktów z hierarchami Niemiec, Francji i Litwy ${ }^{46}$. Pierwsze posiedzenia zespołów odbyły się 8-9 maja 2003 r. w Lublinie i 9 lipca 2004 r. we Lwowie. Zwrócono wówczas uwagę na konieczność dawania świadectw jedności braterskich Kościołów oraz włączenia do dialogu polsko-ukraińskiego szerszych środowisk akademickich i obywatelskich ${ }^{47}$. W roku następnym udało się zorganizować wymianę pielgrzymek do Polski i na Ukrainę. W maju 2004 r. młodzież polska z Lublina brała udział w pielgrzymce do Ławry Zaśnięcia NMP we wsi Uniw w obwodzie Lwowskim, a młodzież ukraińska ze swym zwierzchnikiem kard. L. Huzarem - w spotkaniu młodzieży w Lednicy w Polsce. Na polach lednickich obaj przywódcy Kościołów dokonali symbolicznego aktu przebaczenia i pojednania, wypuszczając w niebo dwa białe gołębie $^{48}$. Podobna wymiana odbyła się 8 i 26 sierpnia do sanktuariów maryjnych w Zarwanicy na Ukrainie i Częstochowy w Polsce ${ }^{49}$. W spotkaniach w Lednicy, Zarwanicy i Częstochowie oprócz grup wiernych wzięło udział duchowieństwo, przedstawiciele episkopatu obu krajów, na czele z prymasem Polski Józefem Glempem i kard. Lubomyrem Huzarem. W dniu 26 sierpnia na Jasnej Górze odbyło się także posiedzenie Biskupów Diecezjalnych, na którym był obecny, jako gość kard. Huzar ${ }^{50}$.

W październiku na zaproszenie ukraińskich grekokatolików przewodniczący Konferencji Episkopatu Polski abp Józef Michalik uczestniczył w obradach Synodu Biskupów Ukraińskiego Kościoła Greckokatolickiego.Wspomniane przedsięwzięcia służyły wzrostowi wzajemnego zainteresowania episkopatów, duchowieństwa i wiernych obu Kościołów. Do pierwszych inicjatorów tej współpracy należał prymas Polski.

Pomimo powolnego postępu, w przekonaniu kard. Huzara, wśród duchowieństwa i hierarchów z obu stron zawsze znajdą się przeciwnicy pojednania na przykład osoby, które przeżyły rodzinne tragedie ${ }^{51}$.

Przytoczone słowa zostały wypowiedziane krótko przed pomarańczową rewolucją na Ukrainie, która miała duży wpływ na ocieplenie relacji polsko-ukraińskich. Solidarność Polaków z Ukraińcami, którzy walczyli o swoją demokrację, oraz rola Polski, jako adwokata Ukrainy w Europie przyczyniła się do stopniowe2010).

${ }^{46}$ Zespoły Konferencji Episkopatu Polski, http://www.episkopat.pl/?a=zespoly (dostęp 17 XI

${ }^{47}$ M. M e 1 n y k, Rola prezydenta..., s. 92-96.

${ }^{48}$ M. F i u t a k, Złowieni nad jeziorem lednickim, „Gość Niedzielny”, 21 VI 2004, nr 23.

${ }^{49}$ П е р е в е з і й, Проблеми..., s. 336.

50 26.08.2004 - Komunikat z posiedzenia Biskupów Diecezjalnych na Jasnej Górze, http:// www.episkopat.-p1/?a=dokumentyKEP\&doc=2004826_0 (dostęp 16 XI 2010).

${ }^{51}$ L. H u z a r, Żeby kochać swoje nie należy nienawidzić cudzego [Rozmawiał Orest Drul], „Ukraïna” 2005, nr 1, s. 91. 
go polepszenia się wizerunku sąsiadów. Tym samym w relacjach polsko - ukraińskich, szczególnie między przedstawicielami młodszego pokolenia, sprawy zaszłości historycznych i uprzedzeń odchodzą na dalszy plan. Ustępują one miejsca pozytywnej koncepcji stosunków dwustronnych, opartych na porozumieniu, partnerstwie oraz wspólnej wizji przyszłości w Europie. Pojawiło się jednak pytanie o zasadność stosowania w sprawie pojednania polsko-ukraińskiego po pomarańczowej rewolucji zasady „grubej kreski”. Przestrzegał przed tym na przykład ks. Tadeusz Isakowicz-Zaleski" ${ }^{52}$.

Jak wiele pracy pozostaje jeszcze do zrobienia w procesie pojednania polsko-ukraińskiego pokazuje stan relacji i współpracy między katolikami obrządku greckiego i łacińskiego na Ukrainie. Wciąż można usłyszeć zarzuty o brak zrozumienia, „podkradanie” sobie wiernych czy wynarodowienie Ukraińców ${ }^{53}$. Nadal pozostaje wiele sprzeczności, w tym spory o świątynie, które należy rozwiązać w duchu deklarowanego porozumienia. Przejawem dobrych chęci i krokiem ku zbliżeniu był gest, uczyniony przez Kościół greckokatolicki na Ukrainie w ramach obchodów 60. rocznicy likwidacji Kościoła greckokatolickiego. Zgodnie z uchwałą Synodu Biskupów z października 2006 r. kard. L. Huzar skierował list do kard. M. Jaworskiego, jako przewodniczącego episkopatu Kościoła rzymskokatolickiego na Ukrainie. W imieniu wszystkich swoich wiernych podziękował on katolikom obrządku rzymskiego za bezinteresowną pomoc, okazywaną greckokatolickim duchownym i świeckim z narażeniem własnego życia w czasach prześladowań totalitarnych. Jako przykład takich osób, wspierających w ukryciu grekokatolików, można wskazać proboszczów łacińskiej katedry we Lwowie ks. Karola Jastrzębskiego, a potem ks. Rafał Kiernickiego. Udzielali oni sakramentów lub umożliwiali ich przyjęcie z rąk , podpolnych” kapłanów unickich działających przy katedrze, opiekowali się zakonnicami unickimi ${ }^{54}$. Do tego klimatu zgody między katolikami obu rytów, pomimo trudnych warunków, nawiązał kilka lat później następca kard. M. Jaworskiego - arcybiskup lwowski Mieczysław Mokrzycki. Pisał o tym w liście gratulacyjnym z okazji 20. rocznicy legalizacji Ukraińskiego Kościoła Greckokatolickiego, który przekazał na ręce kard. L. Huzara we wrześniu 2009 r.

Dokonując przeglądu poczynań Kościoła katolickiego w Polsce i na Ukrainie na rzecz pojednania polsko-ukraińskiego należy zwrócić uwagę, że dostrzeżenie własnego potencjału i znalezienie odpowiedniego miejsca w tym procesie odbywało się dość powoli. Minęło prawie pół wieku od tragicznych wydarzeń konfliktu polsko-ukraińskiego zanim uczyniono konkretne kroki w kierunku zbliżenia. Do pierwszych z takich działań należało rzymskie spotkanie biskupów Kościoła

${ }^{52}$ Między religią a kulturą w Europie..., s. 65.

${ }^{53}$ Zob. np. polemikę kard. M. Jaworskiego z kard. L. Huzarem w wywiadach na łamach „Tygodnika Powszechnego" 2002, nr 46; 2003, nr 1.

${ }^{54}$ J. K r ę t o s z, Wschodnie katolickie obrządki w Polsce, Katowice 2008, s. 75-79. 
rzymskokatolickiego w Polsce z hierarchami Ukraińskiego Kościoła Greckokatolickiego w 1987 r. Przełom odbył się po pielgrzymce Jana Pawła II na Ukrainę w czerwcu $2001 \mathrm{r}$. W następnych latach kontakty między przedstawicielami Kościołów katolickich w Polsce i na Ukrainie ożywiły się, stopniowo zaczęło się pojawiać coraz więcej wspólnych inicjatyw. Chłodne stosunki między narodami jednak nie dadzą się ocieplić w jednej chwili, na przykład przy pomocy samych gestów politycznych. Pojednanie między narodami jest długim procesem, który dojrzewa powoli w sercach i umysłach ludzi. W tym procesie Kościół ma do spełnienia trudne zadanie: uwrażliwienie sumień chrześcijan na cudzą krzywdę i wyznanie własnej winy, kształtowanie postaw moralnych z obowiązkiem przeproszenia za wyrządzone zło i wybaczenia, wyjścia ponad podziały narodowe i skupienia się tym, co łączy - na wspólnej wierze, bez oglądania się wstecz. Nie chodzi o amnezję historyczną, lecz o realizację ideału życia chrześcijańskiego: bycia w prawdzie, która wyzwala, wypełniania podstawowego przykazania miłości bliźniego i okazywania względem niego miłosierdzia. Wszystko wskazuje na to, że misja Kościoła katolickiego na tym polu jeszcze nie została zakończona. 